Милица А. Кандић

Универзитет у Крагујевцу

Филолошко-уметнички факултет

Истраживач-приправник

kandic.milica@filum.kg.ac.rs
УДК: 82.01-1

801.6

DOI: 10.19090/ZJIK.2021.29-41 прегледни научни рад

\title{
ЈАКОБСОНОВА ТУМАЧЕЊА ПОЕТИКЕ
}

САЖЕТАК: У раду Јакобсонова тумачења поетике најпре смо излагали теоријске чињенице у вези са структурализмом како бисмо се упознали са методологијама које су структуралисти користили. Затим смо, испитујући природу знака и односа ознаке и означеног, као и однос језичког система и говорног чина, разматрали утицаје Сосира на структуралисте и формалисте, где смо указали на поимања поетског језика и језика самог по себи. Остатак рада посвећен је текстовима Романа Јакобсона и његовим тумачењима поезије, фолклорне књижевности, приповедака, епских песама, епова и сонета. Различитим тумачењима која су дата кроз Јакобсонове текстове, стекли смо увид у методологију тумачења текстова и у специфичности поетског језика.

Кључне речи: структурализам, Роман Јакобсон, руски формализам, поетска функција језика, приступи поетици

\section{1. УВОД}

Основне теоријске претпоставке о структурализму говоре о немогућности конституисања једне и јединствене методе која би била релевантна за све друштвене и културне потребе. Калер у својој студији Структуралистичка поетика жели да укаже на могућности и ограничења које структурализам са собом носи. Структуралисти се, најпре, баве појмовима знака и означеног и самим појмом значења уопште. Да би се до значења дошло, мора се разматрати систем односа који омогућава конституисање и настанак баш тог значења. Када су посреди уметничка дела или догађаји са значењем, својства тих феномена која их одређују постају и њихове кључне разликовне особине, допуштајући им да буду носиоци унутар симболичког система из кога потичу, чинећи их објектима који су смештени унутар структуре (Калер 1990: 18). Такође је битно напоменути дистинкцију лингвистичких и нелингвистичких знакова јер се они различито третирају. Нелингвистички знакови су природни, те би најприближнији били 
пређашњем разматрању поводом уметничког дела, док би лингвистички знаци подразумевали конвенционалну основу приликом лингвистичког проучавања одређеног феномена (Калер 1990: 18-19). Једна од најбитнијих фигура заслужна за оно што ће структурализам постати јесте Фердинанд де Сосир. Установљујући предмет проучавања структуралиста и подвлачећи разлику између говорног чина (la parole) и језичког система (la langue), битно је утицао на структуралисте, посебно на чланове Прашког лингвистичког кружока, који су чинили Јакобсон и Трубецки. Што се самих термина la langue и la parole тиче, лингвисти су имали подељено мишљење у вези с тим шта припада једном а шта другом. La langue би представљао систем, скуп знакова и правила, a la parole конкретне манифестације система у говору и писању (Калер 1990: 22). Као дистинкција la langue и la parole издвајају се дистинкције правила и понашања и функционалног и нефункционалног. Дистинкцију правила и понашања у вези са la langue и la parole, Чомски је изразио појмовима језичка способност и говорна делатност. Langue или језичка способност представља систем правила или норми којима располажу они који оперишу унутар тог система (Калер 1990: 24). Многа правила су подразумевана, учитана су у језик којим је говорник овладао, што му је омогућило да језичка правила упоребљава и спроводи.

\section{2. КА ЈАКОБСОНОВОМ ТУМАЧЕЬУ ПОЕТИКЕ}

Приликом проучавања неког феномена, структуралисти су се користили диференцијалним вредностима које би успоставиле разлике унутар система два или више феномена. Када се у обзир узму и сличности и разлике одређених феномена, онда се говори о бинарним опозицијама као основном механизму функционисања структуралистичке анализе заслужне за стварање значења. Калер је приликом разматрања бинарних опозиција говорио о предностима али и опасностима, зато што бинарна опозиција допушта класификацију било ког феномена, омогућава настанак категорија у које бисмо смештали елементе само на основу бинарности. Бинарним опозицијама приликом анализа поетских и других текстова бавио се Роман Јакобсон. Због свог структуралистичког приступа, он је био јединствен и умногоме се са руским формалистима није слагао, јер је сматрао да је поетика интегрални део лингвистике и да поетску функцију треба сагледавати у односу према другим функцијама језика (Петров 1970: 75). Увидећемо да је, почевши од ранијих текстова попут онога о Велимиру 
Хлебњикову, па и касније, остао доследан својој методи и да је, сходно томе, тумачио поетске текстове.

Јакобсон је поетску функцију језика сагледавао у односу на остале функције, уочивши да се она не може проучавати само у оквирима поезије. Тако би поетска функција била доминантна функција вербалне уметности, док би у свим другим вербалним делатностима она била споредна (Јакобсон 1966: 294). Поетска функција језика подразумева истицање текста у први план, а у поетском језику свака реч се налази у првом плану, при чему се речи додирују по звуку и сличне су саме по себи (Арсенијевић Митрић 2014: 255). На поетику руског формализма битно је утицала лингвистика и условила настанак Лингвистичког кружока у Москви. Од посебног значаја за руски формализам била је студија Симболизам Андреја Белог, који унутар поетског дела разликује садржај, унутрашњу и спољашњу форму. Бели је био свестан Потебњеве лингвистичке поетике, која се заснива на аналогији речи и књижевног дела и на основу тога наставио је истраживање, при чему је извео закључак да је битно објаснити како је нешто представљено, да би напослетку одговор пронашао у проучавању метра, ритма, у избору звука и речи, чему своја проучавања највише посвећује (Петров 1970: 10-11). Почевши од Белог, руски формалисти почињу да проучавају семиологију, стилистику, семантику, затим метрику, фонетику и фонологију, морфологију унутар стихова песама, па и синтаксу на местима када говоре о положају субјекта и објекта у односу на друге реченичне конституенте.

Руски формалисти поимају језик као вид комуникације; али га исто тако диференцирају према његовим функцијама те тако, почевши од Потебњева и лингвистичке поетике, праве заокрет ка поетском језику као посебној употреби језика која својом специфичношћу захтева посебан вид проучавања. Посебну пажњу плени Јакобсон због својих несвакидашњих тумачења поетског језика, који је, због његове употребе, разликовао од практичног и емоционалног језика. До ових тумачења Јакобсон долази подстакнут познанством са песником Хлебњиковим, што је тек почетак, док ће га на изучавање подстаћи интересовање за француске песнике симболизма. У Разговорима Романа Јакобсона и Кристине Поморске сазнајемо да су неки од кључних момената који су га подстакли на проучавање поетског језика и бављење песничком структуром те односом звука и значења - били занимање за Малармеа и очараност њиме. За Јакобсоново изучавање књижевних текстова у споју са лингвистиком заслужни су и фолклорни текстови, којима су руски фолклористи били 
фасцинирани. Оно што је њихову пажњу нарочито привлачило јесте додир са фолклористичком структуром, где се показало да се и најстарији елементи могу сачувати и доживети непосредно, иако се такве животне прилике чине далеким (Јакобсон, Поморска 1998: 23).

У делима Романа Јакобсона наилазимо на текстове у којима он компаративно сагледава чешку и руску версификацију, што га наводи да се запита над прозодијском структуром језика. Јакобсон је своју пажњу усмерио на размештај и уметничку улогу различитих граматичких категорија на конкретним песничким делима (што ћемо увидети приликом разматрања текстова), док је, с друге стране, посматрао композициону улогу граматичких категорија које се контрастирају (Јакобсон, Поморска 1998: 115). Тако се граматичка композиција песме расветљава с обзиром на архитектонику песме, након чега би уследило разматрање узрока и циљева унутар једне песничке целине.

Јакобсону је пажњу заокупљала поетска функција језика, те се бавио осветљавањем њене функције и посебно издвојио поезију као нешто што се од емоционалног и практичног разликује и има своју аутономност. Речи унутар поезије имају самосталну вредност, али само под условом да морају престати да буду навике због којих прелазимо на представу о означеном, а да нисмо ни свесни звуковних, морфолошких и семантичких особености (Којен 1978: 10-11). То би управо значило да Јакобсон освешћује фонетске, морфолошке, семантичке особености, придаје својим анализама разматрање метрике, стилских фигура, акустике и увиђа контрасте и паралелизме унутар стихова песама као специфичности песничког језика. Сходно тој посебности песничког језика, Јакобсон је приступао на један специфичан начин, разматрајући поезију као бављење ванјезичким чињеницама и усредсређивање на израз унутар песничке форме. Песнички језик одликује се елементима који на другачији начин функционишу због специфичне употребе и усмерености на говор (Којен 1978: 42). Калер и Рифатер овакво тумачење одбацују, као и многе идеје које се односе на разматрање граматике поезије. Будући да се разликује од говорног језика, поезију није могуће свести на једно значење а ни парафразирати, јер својом структуром измиче поимању текстовног. То нас наводи на разматрање онога што су формалисти називали функционална специфичност песничког језика, јер речи унутар поетског језика, и једино унутар њега, добијају аутономност. Оваква претпоставка чини се непотпуном зато што нам не објашњава начин на који песнички језик стиче специфична обележја, већ нам само открива 
шта је карактеристично за поезију у односу на друге врсте језика (Којен 1978: 17). Када је реч о поетској функцији, Јакобсон увиђа њену подложност изменама, те би је, у зависности од поетског текста, требало изнова запажати посматрањем елемената који постају доминантни унутар језичке структуре песме.

\section{3. О ЈАКОБСОНОВИМ ТУМАЧЕЮИМА ПОЕТИКЕ}

На инсистирање футуриста (Хлебњиков и Мајаковски), који су експериментисали језиком стварајући слободне ритмове, нове речи, уводећи термин „заумни језик“ - алегорични језик, проистекла су запажања поводом аутономности речи унутар песничког језика. Јакобсон је, подстакнут познанством са Хлебњиковим, увидео значај за руски формализам и, сходно томе, настаје његов текст „Велимир Хлебњиков“. У овом тексту Јакобсон нам скреће пажњу на то да песма оживљава на језичком плану и да су лингвистичка запажања кључна за тумачење модерне руске поезије, те да су Хлебњиков и Мајаковски у том погледу ближи од Пушкина. Оно што је такође битно напоменути јесте чињеница да Јакобсон (Јакобсон 1970: 96) прихвата све елементе савременог песничког језика и пореди га с три момента: са постојећим песничким традицијама, са практичним језиком садашњице и са песничком тенденцијом која је претходила датој појави. Овом тврдњом најављен је став којим ће се Јакобсон убудуће водити приликом анализа песама. Дакле, он ће савремену поезију доводити у везу са претходном традицијом која је проузроковала промене у садашњости, али ће и песнички језик доводити у везу са практичним језиком. Спомињући Пушкина, Јакобсон говори о традицији као о калупу, али и о могућности серијске производње песама сличних Пушкиновим. Модерна поезија се тим калупима не служи, користи се формом само онолико колико би се могао постићи отпор према постојећим темама и другим елементима песничког језика. Још једно кључно запажање било би да се на поезију претходних стваралаца никако не може пројектовати савремена поетика, већ да се треба тумачити у оквирима поетике у којима је песма стварана. Јакобсон прави паралелу у тумачењу књижевности и језика, те даје пример дијалеката којима би лингвиста дао вредност и пореди их са претходним или пак неким другим дијалектима. Функција такве паралеле јесте извођење закључка да би се теорија песничког језика развила тек онда када би поезија била посматрана као социјална чињеница, када би се створила одређена песничка доктрина и када би поезија била самеравана према усвојености претходних 
утицаја. Расветљавање футуризма има функцију да читаоце обавести о томе како нова форма у футуризму условљава и нови садржај и да се, обрађујући постојеће теме, има још понешто рећи и обзнанити у сасвим другачијем светлу. С обзиром на нову форму и садржај, и на језичком плану одигравају се битне промене. У песничком језику (као и у емоционалном) појмови привлаче на себе пажњу, док је семантичка и фонетска страна речи у тешњој вези, самим тим је језик револуционарнији и постиже се потискивање асоцијација у други план (Јакобсон 1970: 101). Будући да представља поезију језиком у својој естетској функцији, Јакобсон говори о томе да је језик главни чинилац поезије, а да је његова функција заправо начин на који је песник обликује унутар песничке форме. У прилог овој тврдњи Шкловски говори о поезији као уметности мишљења у сликама која захтева посебан начин размишљања - мишљења помоћу слика, где је њен основни задатак да групише разнородне предмете и да непознато објасни познатим (Шкловски 1970: 81). Када је језички план посреди, ситуација је нешто другачија, што нам објашњава Јакобсон. Користећи се језиком, у поезији се постиже брисање граница између реалних и фигуративних значења, али се укида и мотивисаност предмета његовом претходном природом. Уводећи појам логичке противречности, Јакобсон промишља о томе да се логичка противречност јавља на плану поезије и да се поезија не подудара са стварношћу, али и скреће пажњу на чињеницу да се унутар поезије суочавамо најчешће са језичким чињеницама, не толико са мислима. Тврдњу илуструје примерима - формални паралелизми не прате семантичке паралелизме, при чему се наглашава истоветност падежних облика који имају различито значење. Јакобсоново схватање природе речи у поезији неће ce битно изменити, jep ће и даље бити присутно инсистирање на усмерености на језик које датира од његовог првог текста о Хлебњикову (Арсенијевић Митрић 2014: 252).

Текстом „Шта је поезија“ Јакобсон жели да укаже на значај онога што је поезија била, тј. који елементи поезије су за песму били предодређујући. Од епохе до епохе списак тема се мењао, допуњавао и смањивао, али је модерна поезија својим присуством за све теме била обједињујућа, те тако не постоји тема која је више или мање песничка. Честе су расправе и полемисања о томе шта је стварно, а шта није. Исто тако наилази се на биографске елементе кроз чију се призму дела тумаче, што је чест случај књижевних критичара. У овом случају настају бројни проблеми који штете делу и ограничавају га. Бавити се само биографским тренуцима и 
реконструисати дело помоћу биографије исто је тако погрешно као и занемарити елементе биографизма. Јакобсон (Јакобсон 1978: 108) наводи да су многи књижевноисторијски радови били усмерени на психичку реалност и песничку фикцију, тражећи у тој релацији каузалност по тачно одређеном механизму. Дајући пример Махе, Јакобсон објашњава појаву биографских и дневничких елемената унутар Махине поезије и указује на прожимање поезије и приватног живота. Разматра се и начин на који догађаји путем поетског језика бивају стилизовани и делимично измењени. Важност текста огледа се у томе што се жели указати на чињеницу да је временски условљена садржина појма поезија променљива и нестабилна категорија, подложна променама, јер ступа у однос са другим дисциплинама социјалне структуре. Оно пак што је стабилно јесте поетска функција језика, чији се елементи не могу разложити на друге елементе (Јакобсон 1978: 117). Поетска функција доводи се у везу са песничким делом тако што га одређује и организује, али на начин да ни поетска функција као ни песничко дело нису доминантни над осталим вредностима.

Пре него што приступимо разматрању Јакобсонових метода, које се тичу лингвистичке анализе илустроване примерима конкретних књижевних дела, неопходно је говорити о тексту „Несвесне језичке структуре у поезији“ и ономе што је он називао „несвесним језичким структурама“. Под „несвесним песничким структурама“ подразумевао је да лингвистичке структуре откривене анализом унутар текста могу настати и несвесно. Процес стварања песме, био свестан или не, подразумева одређени избор језичког материјала који песници користе стварајући песму. Јакобсон истиче важност варијанти песама, јер се приликом њиховог разматрања разоткрива постојање/непостојање песникове свести о језичком материјалу. Приликом сагледавања варијаната, закључује се да читалац и песник увиђају уметничку предност контекста који поседује одређене компоненте (у новој варијанти) у односу на контекст у коме се те компоненте не јављају (Јакобсон 1978: 186). Песник у песму најпре инкорпорира оне језичке обрасце и версификацију које сматра неопходнима, док остале елементе додаје накнадно, те су они подложни изменама, трансформацијама и слично. Као пример наводи песника Велимира Хлебњикова, коме је, закључује Јакобсон, промакло то да је област правилних фонолошких понављања много шира, те анализира примере фонема унутар стихова на којима је то запазио. С једне стране, Јакобсон наводи Хлебњикова као ствараоца који делимично свесно користи језички материјал, док се са друге стране налазе фолклористи и народна 
традиција, унутар које стваралац не разазнаје ни основни језички материјал, већ зна да оцени потпуну форму и да је одвоји од оне девијантне, често и не знајући да објасни зашто се за ту варијанту одлучио. Проучавањем фонетског и фонолошког, морфолошког, синтаксичког и метричког склопа загонетки, Јакобсон изводи закључак да је њихова језичка структура згуснута и да су римоване целине најчешће граматички и прозодијски паралелне. Ексцерпираним примерима из руских загонетки желео је да илуструје заједничке особине које се односе на непостојање глагола, чиме се разлика између атрибута и предиката с нултом копулом брише, а потом да укаже на чињеницу да је одгонетка најчешће именица са значењем „неживог“ која се замењује именицом супротног рода са значењем „живог“ (Јакобсон 1978: 190, 191). Као закључну напомену у вези са текстом „Несвесне језичке структуре у поезији” Јакобсон наводи да је често интуиција стваралаца заслужна за настанак сложених фонолошких и граматичких структура.

Коауторски текст Романа Јакобсона и Гојка Ружића „Српски Змај Огњени Вук и руски еп о Всеславу“ значајан је због компаративног тумачења на коме се Јакобсонова методологија проучавања заснива. Текст са другачијег аспекта осветљава сличности српске епске песме и руског епа, будући да их разматра са историјског и митолошког становишта. Полазна тачка јесте чињеница да је изворни еп својеврсна прерада старог словенског мита о вукодлаку. У тексту је уочено да је митолошко наслеђе на сличан начин обрађено и у српској и у руској епској традицији и да је мит употребљаван као епски заплет (Јакобсон 1966: 21). Личности као Всеслав и Змај Огњени Вук повезиване су најпре са историјским личностима, а затим су сагледаване у односу на митологију, где су трансформације јунака такође запажене. Почевши од рођења оба јунака, наговештена је њихова посебност и поседовање надљудских способности попут моћи трансформације, велике снаге и ознака на телу (нпр. белег). Такође се јавља и мотив освете јунака над змајем због силовања мајке, а заједнички елементи су и чуђење и преплашеност мајке својим дететом које поседује натприродне моћи. Оба јунака у свом детињству брзо напредују и одрастају у јунаке. Као једна од разлика између српске епске песме и руске биљине наводи се да српска епска традиција тежи да ограничи присуство јуначких трансформација, те је Змај Огњени Вук спретан ловац и ратник, али тако да асоцира на зооморфне одлике јунака или се животиње појављују око јунака као помагачи. Још једна паралела која се назире јесу трагичне судбине јунака. Поређењем песме и епа 
долази се до закључка да је у основи мит - примитивна словенска тема. Овај текст доноси другачију анализу од претходно анализираних текстова, јер се бави компаративним тумачењем епске песме и биљине са митолошког и историјског аспекта, откривајући да таква методологија најпотпуније објашњава посматрана дела.

Текст „О руским бајкама“ такође спада у специфична разматрања различитих у односу на анализе на које смо навикли, које обухватају највећи део методологије Јакобсонових тумачења књижевних дела. Специфичност овог текста огледа се у разматрању начина прикупљања народних приповедака, за шта је Афанасјев био нарочито заслужан. Од тог тренутка започело је интересовање и за усмени руски говор, поезију, али и за њихова проучавања. Такође се скреће пажња на специфичности поводом разликовања усмене и писане књижевности - писана књижевност је верског карактера, окренута је религијским текстовима, а усмена своју примену има у приповеткама и бајкама. Разликовање је било најпре функционалне природе, јер се никако није могло замислити да верски текстови буду усменим путем извођени и преношени. Међутим, све више долази до брисања граница између црквеног и световног, књижевности и фолклора, писаног и говорног језика. Пратећи развој усмене и писане књижевности кроз векове, уочава се утицај фолклорних елемената на писану књижевност. XVII век доприноси изменама фолклора који се записује, те постоји проблем када је бележење приповедака у питању, јер многе нису сачуване данас, док се за њих нису заузели страни путници који су их бележили (Јакобсон 1966: 35). Од XVIII века интересовање за бележење је порасло, где је посебно истакнута Афанасјевљева ризница бајки. Али оно што је Афанасјеву било замерено јесте вештачко конструисање текстова помоћу неколико варијаната исте приповетке. Доброљубов је, увидевши то, говорио сакупљачима да у обзир буду узете и варијанте приликом бележења песама, приповедака и других творевина народа.

Искуство модерне лингвистике показује да језички узорци показују доследну правилност. Језици целог света показују мали број и релативну једноставност структуралних типова, а у основи свих тих типова леже универзални закони (Јакобсон 1966: 41).

Увиђањем правилности унутар лингвистике, тумачење се преноси на законитости које су у основи свих типова универзалне и запажа се да се слични феномени схематизације и поновљености у структури јављају у 
приповеткама широм света. Говорећи о карактеристикама усмене традиције, посебно је важна употреба приповедака и њена везаност за свакодневног човека. Осим тога, запажа се структура руских приповедака као нешто што се у приповеци неизоставно мора наћи и о чему се водило рачуна када је форма у питању. Када је реч о руској фолклорној књижевности, Андрејев је желео да испита оригиналност фабула у руским приповеткама проширивши Арнеов индекс европских прича, додајући му фабуле које је у приповеткама могао да уочи. Руске фабуле, износи Јакобсон (Јакобсон 1966: 49), односе се на кратке приче и анегдоте, а средина приказана у причама на друштвеној лествици је ниже у односу на бајке. У овом тексту испитана је руска фолклорна књижевност од најранијих сакупљачких делатности и погрешака приликом њиховог прикупљања, па до савременијих испитивања и проучавања елемената фолклористике. Јакобсон је овим текстом желео да укаже како на односе према фолклористици тако и да размотри специфичности везане за форму и структуру приповедака и бајки. Низ специфичности које истиче упућују на Јакобсонову фасцинацију фолклористиком, што смо могли запазити и у претходном тексту, у коме компаративно проучава српску епску песму и руски еп.

Јакобсоновим текстом „Шарл Бодлер: Мачке“ завршавамо разматрања поводом његових тумачења поетике. У тексту се уочавају два дела: први део који се тиче метрике, фонолошке и морфолошке анализе, док други део прати трансформацију мотива мачке на семантичком плану (повезујући мотив са граматичким материјалом у песми). Јакобсон дели стихове према метрици да би запазио мушке и женске риме, одредио њихову морфолошку структуру и закључио да су на плану метрике и морфологије стихови унутар сонета супротстављени. Основу супротстављености чини подељеност стихова на два катрена и две терцине, а потом и граматичка организација стихова. Такође је указивао на паралелизме првог катрена и прве терцине и другог катрена и друге терцине и то поткрепљивао примерима о живим бићима која се у оквиру подмета терцина и катрена јављају. Затим је у спољашњим строфама запазио жива бића у првом катрену, а нежива у другој терцини, чиме се увиђа дијагоналност и супротстављеност спољашње и унутрашње строфе. Јакобсон запажа подударност и на почетку као и на крају сонета, када посматра граматичку структуру. Вршећи морфолошку анализу, долази до закључка да је треће лице употребљено у сонету као и да су именице, придеви и заменице чести елементи стихова. Након разматрања о структури, пажња се усмерава на 
метаморфозу мачака кроз песму. Најпре се на фонетском плану - преко гласова најављује присуство мачке и њено именовање, затим се до краја сонета мачке појављују само као заменице. Унутар стихова уочљива је супротстављеност обједињена једним бићем - мачком, у катрену се приказује личност мачке и њена повезаност са човеком, док терцине указују на преображења (Јакобсон 1966: 107). Спајајући мачку са особинама човека, означено које познајемо мења своју суштину и припрема читаоце за метаморфозе (сфинге, натприродна бића). Приликом те метаморфозе сагледава се начин на који мачка као мотив постаје предмет и део граматичке структуре, те бива везана за предмет прелазног глагола у завршним стиховима сонета. Трансформација је уочљива и на нивоу синтаксе реченице, где се сагледава како мачка као биће/предмет функционише у зависним реченицама. Анализа која је спроведена са различитих аспеката проматра сонет, наговештавајући да се сви елементи обједињују у сонету. Мачка се кроз стихове јавља преко стилских фигура као њених различитих испољавања (хијазам, метафора, метонимија), а преко супротстављених стихова и елемената остварује се трансформација. Закључујемо да је метафора од кључне важности за сонет, а да се метафоричким поступком постиже преображај мачке (од везе са човеком, преко митологије, до мачака у космичком пространству). Двојство је, наслућујемо, важно за саму структуру, јер на њој почива и уприсутњено је кроз читав сонет. Тако текст мири и разматра супротности приступајући им са различитих аспеката, што смо Јакобсоновом анализом Бодлеровог сонета „Мачке” могли да запазимо. Као форма, сонет обједињује све супротности било да је на нивоу фонема, морфологије, синтаксе, семантике било да су у питању мотиви, стилске фигуре, слике. Све наведене специфичности поезију чине јединственом структуром изузетне садржајности и разноврсности, а стих као форму унутар које се сви садржаји на јединствен начин реализују.

\section{4. ЗАКЉУЧАК}

На основу свега до сада реченог, закључујемо да Јакобсонова тумачења и проучавања поетике подразумевају одређене методологије којима се кроз своје текстове руководио. Третирајући поетски језик као специфичну употребу језика, која одудара од оне свакодневне, са тог аспекта му је и приступао, проучавао је његове специфичности и покушавао да својим текстовима и разноврсним примерима (почевши од биљина, загонетки, пословица, бајки, приповедака до песама руских футуриста) 
укаже на различите манифестације тих особености. Користећи се фонетском, фонолошком, морфолошком, синтаксичком, семантичком, метричком и стилистичком анализом, темељно приступа текстовима првенствено као језичком материјалу, настојећи да са различитих аспеката осветли везу лингвистике и поетике у својим тумачењима. Међутим, често је анализа имала за циљ да прикаже организацију граматичких елемената унутар поезије, те је занемаривао поетичке аспекте тумачења, што његову методологију доводи у питање, о чему су многи проучаваоци структурализма говорили. Упркос томе, Јакобсон је због дефинисања и објашњавања функције поетског језика остао упамћен, као и због своје исцрпне методологије која је многе проучаваоце подстакла да се и сами тиме баве и да његове методе разрађују и унапређују.

\section{ЛИТЕРАТУРА}

Арсенијевић Митрић, Јелена. 2014. „Еволуција мисли Романа Јакобсона“. У: Бошковић, Д. (ур.). 2014. УСКРСНУЋЕ књижевности: 100 година руског формализма. Крагујевац: Филолошко-уметнички факултет, 245-257.

Jakobson, Roman. 1966. Lingvistika i poetika. Beograd: Nolit.

Jakobson, Roman. 1970. Poetika ruskog formalizma. Beograd: Prosveta.

Jakobson, Roman. 1978. Ogledi iz poetike, Beograd: Prosveta.

Јакобсон, Роман. Поморска, Кристина. 1998. РАЗГОВОРИ: Лингвистика, поетика, култура XX века. Београд: Народна књига-Алфа.

Калер, Џонатан. 1990. Структуралистичка поетика. Београд: Српска књижевна задруга.

Kojen, Leon. 1978. „Jakobsonova poetika“. U: Komnenić, M., Kojen, L. (ur.). 1978. Ogledi iz poetike. Beograd: Prosveta, 7-46.

Petrov, Aleksandar. 1970. „Poetika ruskog formalizma“. U: Petrov, A. (ur.). 1970. Poetika ruskog formalizma. Beograd: Prosveta, 7-78.

Šklovski, Viktor. 1970. „Umetnost kao postupak“. U: Petrov, A. (ur.). 1970. Poetika ruskog formalizma. Beograd: Prosveta, 81-94. 
Milica A. Kandić

\section{JAKOBSON'S INTERPRETATION OF POETICS}

\section{Summary}

In Jakobson's interpretation of poetics we first showed the theoretical facts connected to structuralism so that we could get to know the methodology used by structuralists. After that, we have, by questioning the nature of the sign and the relation between the signifier and the signified, as well as the relationship between the linguistic system and the speech act, analyzed the influence of Saussure on structuralists and formalists where we have pointed out to the understanding of poetic language and the understanding of language itself. The rest of the work is dedicated to Roman Jakobson's texts and his interpretation of poetry, folklore literature, short stories, epic poems, epic tales and sonnets. Through the various interpretations that are given by Jakobson's texts, we have gained insight into the methodology of text interpretation, as well as the specificities of poetic language. With his research, Jakobson contributed to the creation of a unique approach to interpretation of poetic texts because he united the linguistic and poetic approaches showing innovation in his interpretation of texts.

Key words: structuralism, Roman Jakobson, Russian formalism, poetic function of language, approaches to poetry 
